\title{
Principals' Instructional Supervision Practices: Key to Kiswahili Academic Performance
}

\author{
Dr. Rose Mwanza (PhD) \\ School of Education, South Eastern Kenya University, Nairobi, Kenya
}

Dr. Lucia Musyoka (PhD)

Doi:10.19044/esj.2018.v14n28p128 URL:http://dx.doi.org/10.19044/esj.2018.v14n28p128

\begin{abstract}
This study evaluated the principals' instructional supervision practices as key to Kiswahili academic performance in public day secondary schools in Nairobi County, Kenya. Secondary school principals' instructional practices are paramount in enhancing academic performance among secondary school students. Quality and relevant instruction ensures excellent academic Kiswahili achievement of students. Through instructional supervision offered by the principals, teachers are stimulated, supported and motivated to instruct the students well. For instructional supervision to fully benefit schools, both the principals and the teachers need to play a meaningful and effective role. The improvement of school through instructional supervision has been a concern for education stakeholders in Kenya during colonial and after colonial periods. As a result, Education Commissions which were formed to evaluate the education system in Kenya addressed the status of Kiswahili. The education Commissions included Phelps Commission of 1924 which recommended the use of vernacular and Kiswahili for teaching practical subjects, and Presidential Working Party for the Establishment of Second University of 1981 which called for teaching of Kiswahili as a compulsory and examinable subject in both primary and secondary schools. The current study targeted 26 public day secondary schools, 26 principals, 26 heads of department of Kiswahili and 2664 students. Both probability and nonprobability sampling techniques were used in the study. The objectives of the study included: What instructional materials are used by Kiswahili teachers to ascertain performance in Kiswahili; what measures are put in place by secondary school principal to realize performance in Kiswahili; what are the strategies directed towards enhancing Kiswahili teachers' skills in public day secondary schools in Nairobi County. Descriptive research design was adopted for the study. Data analysis techniques included stratified random sampling, proportional allocation, simple random sampling design and purposive
\end{abstract}


sampling designs. Instruments for data collection included two sets of questionnaires and interview guide. Statistical Package for Social Sciences (SPSS) was used to calculate frequencies and percentages. The key findings of the study were that lack of the instructional materials may have contributed to poor performance in Kiswahili; school principals executed their duties properly as concerns Kiswahili teachers' lesson attendance and that lack of concern of principals in what students learn in school may have led to poor performance in Kiswahili.

Keywords: Principals' Instructional Supervision Practices, Kiswahili Academic Performance

\section{Introduction}

Kiswahili is a national and an official language in Kenya. The Government of Kenya has put a lot of effort to enable Kenyans read and write as well as speak it. There are a number of Commission Reports written during pre-colonial and post-colonial times that recommend the promotion of the Kiswahili language. These Commission Reports include Phelps-Stroke Commission of 1924 which recommended the use of vernacular and Kiswahili for teaching practical subjects such as agriculture and carpentry, Kenya Education Commission of 1964 which recommended that Kiswahili be made compulsory in primary schools as a unifying influence (Republic of Kenya 1964) and Presidential Working Party on the Establishment of the Second University of 1981 which called for teaching of Kiswahili as a compulsory and examinable subject in both primary schools and secondary schools.

Instructional supervision refers to the processes by which secondary school principals try to achieve acceptable standards of performance and results through facilitating teaching and learning in the schools by monitoring both students' and teachers' work (Sule, Arop \&Alade, 2012). Tyagi (2010) highlights that instructional supervision in secondary schools improves the teaching-learning process for the benefits of both the teachers and learners. Tyagi, further argues that secondary school principals' instructional supervision assists in the detecting of areas that need follow-up activities that ought to be directed at the improvement of learning and teaching process.

Akinola (2010) conducted a study in Nigeria and found out that secondary school students' academic performance in external examinations had been low. The study established that out of 1,351,557 candidates who sat for May/June 2010 West African Senior School Certificate Examination, only 337071 candidates representing 24.94 percent obtained credits in English Language and Mathematics. According to Akinola's study, the poor academic attainment was as a result of the educational management practices which had 
been earlier ignored. The objectives of the study included: What instructional materials are used by Kiswahili teachers to ascertain performance in Kiswahili; what measures are put in place by secondary school principal to realize performance in Kiswahili; what are the strategies directed towards enhancing Kiswahili teachers' skills in public day secondary schools in Nairobi County.

\section{Instructional Supervision and Academic Performance of Day Secondary School Students}

If the instructional supervision practices by principals are to fully benefit schools, both the principals and the teachers need have to play their roles in a meaningful and effective way. According to Moswela (2010) study carried out in schools through a structured questionnaire and interview guide in Bostwana, on situational supervision, it was evident from the findings that both primary school teachers and head teachers' environment in which instructional supervision took place was rather hostile and intimidating to them. This hindered them from making any meaningful impression on the enhancement of instructional standards. This view was in- agreement with the findings by Wachira (1996) who investigated the influence of secondary school principals' administrative performance on students' educational attainment in Nairobi City County. Wachira found out that principals faced problems of unusual behavior of students which manifested itself in general indiscipline such as truancy, non-attendance and drug abuse. The researcher was motivated by Wachira's findings and wanted to establish whether what Wachira's study established about problems facing head teachers' in Nairobi City County may also be a contributory factor to poor performance in Kiswahili in public day secondary schools in Nairobi County in the current study.

In addition, a study conducted by Sidhu (2010) in Malaysia assessed the significant role of primary school head teachers in relation to the supervision of the teaching and learning process in Malaysian primary schools. The study sampled 29 primary school heads. Research instruments included questionnaires and documentary analysis. The study found out that instructional supervision of the head teachers lacked some of the mandatory practices. Most of them lacked knowledge of their role position in relation to instructional supervision and what their mandate entailed. Sidhu concluded that the head teachers ought to possess knowledge, understanding and gather as much information as possible concerning instructional supervision.

Secondary school principals should share information during staffmeetings to improve intra-staff cooperation and service to students (Klein, 2012). According to the aforementioned researcher, there are a number of issues that the school principals need to address before the results of instructional supervision can be achieved by teachers and enhancement of 
students' learning. On the same note, a study conducted by Odera (2014) in Nyakach in Kenya on learning Kiswahili by radio in secondary schools established that the utilization of school radio program was found by teachers as a useful tool for teaching and learning Kiswahili. This study therefore intended to establish principals' instructional supervision practices as key to Kiswahili academic performance in public day secondary schools in Nairobi County, Kenya.

\section{Methodology}

The study adopted a survey research design. The study targeted 26 public day secondary schools, 26 principals, 26 heads of department of Kiswahili and 2664 students (Ministry of Education, 2014). The study used both probability and non-probability sampling procedures. Stratified random sampling, proportional allocation, simple random sampling design and purposive sampling design were used in the study. To sample schools that participated in the study, the researcher selected $35 \%$ of the total population of 26 secondary schools which was 9 secondary schools. Gay (1996) suggests $10 \%$ of large populations and $20 \%$ of small populations as minimums. Therefore, $35 \%$ of the total population of 26-day secondary schools was more representative than $20 \%$. A sample size of $10 \%$ according to Gay of the entire population if well selected can be representative of the desired population. The public day secondary schools in Nairobi County were split into three homogeneous categories, that is, boys only secondary school category, girls only secondary school category and mixed secondary school category. The number of secondary schools in each category was 9 boys only secondary schools, 6 girls only secondary schools and 11 mixed secondary schools. To get a sample size of total population of students in each category of public day secondary schools in Nairobi County, the researcher considered Gay's (1996) method of selecting sample size. Ten percent (10\%) of the total population of students in each category included 118 boys only secondary schools' category, 45 girls only secondary schools' category and 103 mixed only secondary school category. The principals and heads of Kiswahili department in the sampled public day secondary schools were purposively sampled to participate in the study.

The study adopted (Kothari, 2004) proportionate allocation method to get a sample size for each category of secondary schools. The following is the method adopted: P:n(i/N)

Key: $\mathrm{P}=$ proportion of population included in stratum $\mathrm{i}$

$\mathrm{n}=$ total sample size

$\mathrm{i}=$ number of elements in the stratum

$\mathrm{N}=$ population size

$\mathrm{n}=9$ (Total sample size) 
$i_{1}=9$ (Number of schools in the boys only category).

$i_{2}=6$ (Number of schools in the girls only category).

$i_{3}=11$ (Number of schools in the mixed category).

$\mathrm{N}=26$ (Total number of schools in the three categories).

Therefore, the number of elements selected from stratum $\mathrm{P}_{1}, \mathrm{P}_{2}$ and $\mathrm{P}_{3}$ was as follows:

$$
\begin{aligned}
& \mathrm{P}_{1}: 9(9 / 26)=3 \\
& \mathrm{P}_{2}: 9(6 / 26)=2 \\
& \mathrm{P}_{3}: 9(11 / 26)=4
\end{aligned}
$$

The instruments for data collection in the study included two sets of questionnaires and an interview guide. Two questionnaires were generated; one for public day secondary school principals and the second for form three students while interview guide was generated for heads of department of Kiswahili. The questionnaire for principals contained eight sections. Section A had demographic data, section B home environment of the learner, section C availability and adequacy of instructional materials, section D instructional supervision by the school principal, section E enhancing Kiswahili teachers' skills, section $\mathrm{F}$ instructional techniques, section $\mathrm{G}$ language policy and section $\mathrm{H}$ influence of other languages. The questionnaire for students had seven sections. Section A contained demographic data, section B home environment of the learner, section $\mathrm{C}$ availability and adequacy of instructional materials, section $\mathrm{D}$ instructional supervision by the school principal, section $\mathrm{E}$ instructional techniques, section $F$ language policy and section $G$ influence of other languages, while interview guide for heads of Kiswahili department had eight sections: Section A concerned demographic data, section B home environment of the learner, section $\mathrm{C}$ availability and adequacy of instructional materials, section D instructional supervision by the school principal, section E enhancing Kiswahili teachers skills, section $\mathrm{F}$ instructional techniques, section $G$ language policy and section $H$ influence of other languages. Statistical Package for Social Sciences (SPSS) was used to calculate frequencies and percentages.

\section{Research Findings}

The study sought information from heads of department of Kiswahili on availability of instructional materials that were lacking in school. The study established that $9(88.9 \%)$ did not have Kiswahili literature textbooks while $1(11.1 \%)$ indicated the school did not have Kiswahili language textbooks. Other instructional materials that were lacking according to heads of department of Kiswahili included computers and projectors cited by 4(44.4\%) of the respondents, revision books and Taifa Leo Newspapers indicated by $3(33.3 \%)$ of the respondents while $2(22.2 \%)$ said their schools lacked radio. From the findings it was concluded that lack of instructional materials may 
have contributed to poor performance in Kiswahili. According to Odera's (2014) study, the use of other instructional materials other than textbooks in teaching and learning process motivated students to want to learn. For example, Odera's study revealed that language programs on radio helped to increase the students' mastery of vocabulary and pronunciation.

The study sought information on Kenya Certificate of Secondary Education (KCSE) mean score in the year 2015 in the principals' questionnaire. The findings showed that $1(11.1 \%)$ out of nine respondents indicated that mean score was 8.02, 2(22.2\%) indicated that the mean score was $6.52,1(11.1 \%)$ indicated that the mean score was $5.9,2(22.2 \%)$ indicated that their schools had a mean of 4.2 and $2(22.2 \%)$ indicated that the mean score was 2.0. The mean score for the total number of nine sampled schools is 5.0. According to the national examination grading system used by Kenya National Examination Council (KNEC), 5.0 is grade $\mathrm{C}^{-}$(MOE 2009). The highest grade is grade ' $\mathrm{A}$ ' of 12 points. The low mean grade in the sampled schools confirms that public day secondary schools in Nairobi County performed poorly in Kiswahili. The study sought information on strategies the principals used to ensure that Kiswahili teachers attended Kiswahili lessons. The findings of the study showed that $9(100 \%)$ of the principals checked daily class attendance of teachers, $9(100 \%)$ indicated of the principals indicated that the school prefects filled in the lesson attendance sheets and $5(55.6 \%)$ stated that the principals wrote memos to those who did not attend lessons. According to the findings obtained in Sidhu's (2010) study, majority of the head teachers did not know their role in instructional supervision. The findings in the present study indicate that school principals executed their duties properly as concerns Kiswahili teachers' lesson attendance.

The study also sought information on communication method used by principals to provide information to teachers. The findings were that $5(55.6 \%)$ of the principals called for brief staff meeting and $4(44.4 \%)$ of the principals indicated that they wrote memos. From these findings, it is clear that more than half, $5(55.6 \%)$, of the principals used brief staff meeting as a method of communication. Staff meeting is an effective method of communication since it may create a good working atmosphere for both the teachers and the principal. According to findings of a study by Klein (2012), staff meetings improved intra staff- co-operation and service to the students. On the other hand, Heads of department of Kiswahili gave the following responses concerning the strategies the principals used to enhance performance in Kiswahili. Six $(66.7 \%)$ of the Heads of department of Kiswahili indicated that the principals bought learning materials as a strategy for enhancing performance in Kiswahili, 7(77.8\%) indicated that the principals gave rewards to good performers in Kiswahili and $8(88.9 \%)$ indicated that the principals took students to national theatre. These findings reveal that the principals 
enhanced students' learning by addressing issues such as buying of learning materials and taking students to national theater to watch Kiswahili played an important role in enhancing the students' communication skills.

The study sought information on how often the principals checked students Kiswahili homework. The students who were the respondents responded as follows; 151 (56.8\%) indicated that their schools principal very rarely checked their Kiswahili homework, 9(3.4\%) stated that very often the principal checked their Kiswahili homework, 10(3.8\%) indicated that the principal often checked their Kiswahili homework, 56(21.1\%) of the respondents were not decided and $40(15 \%)$ indicated that the principals rarely checked their Kiswahili homework. These findings concur with Wachira's (1996) study which was conducted in Nairobi County on 'Implication of Secondary School Head Teacher's Administrative Performance'. The study established that head teacher's administrative performance was related to students' academic achievement. In the present study, majority, 151(56.8\%), of the respondents stated that the principal very rarely checked their Kiswahili homework. Lack of concern of principals in what students learn in school may have led to poor performance in Kiswahili in public day secondary schools in Nairobi County.

\section{Recommendations}

Recommendations were made to various stakeholders in the education sector. In the study, it was established that performance in Kiswahili was a joint responsibility of all the stakeholders including the principal. The following were the recommendations proposed in this study: The study recommended that the principals should come up with strategies that would ensure that the students who do not do their Kiswahili homework be guided accordingly; The study further recommended that the schools should put in place measures to ensure that students who were needy were retained in school; The study further recommended that public day secondary schools come up with projects that would generate money to support needy students by instructional materials.

\section{References:}

1. Akinola, W.(2010) WAEC: Who to blame for students' poor performance? Nigerian Compass. Retrieved from http:www.compassnewspaper.com accessed on 10 October, 2013.

2. Klein, J. (2012). Effectiveness of staff meetings: implication for teacher-training and method in, Journal of Education, Vol. 28, No. 1, April 2005, pp. 67-81.

3. Kothari, C. R. (2004). Research Methodology. India: New Age International $(\mathrm{P})$ Limited Publishers. 
4. Ministry of Education (2014). 2009-2013 KCSE Results Analysis. Nairobi: Government press, Kenya

5. Moswela, B. ( 2010). An Investigation into instructional supervision in Botswana secondary schools. Botswana: Sage Journals,2(11), 106111.

6. Odera, F. Y. (2014). Learning kiswahili languages by radio at distance secondary schools; Conduct of Meetings. Bar Ilan University,Isreal: International Journal of Research and Compass. Retrieved from http:www.compassnewspaper.com/NG/index.php?option development of teachers Compare

7. Sidhu G. K. (2010). Supervision of Teaching and Learning Issues and Concerns for the Schools in Nyakach. Nairobi: (Unpublished Thesis).

8. Sule, M. A., Arop, F. O. \& Alade, F. O. (2012). Principal's Classroom Visitation and Inspection, Their Administrative Performance: A Case Study of Nairobi Province. Unpublished Doctorte Thesis, University of Nairobi.

9. Tyagi, R. S. (2010). School-Based Instructional Supervision and the Effective Professional Teaching. Unpublished Master of Education Thesis, Kenyatta University

10. Wachira, N. (1996). Preparation of secondary school head teachers and implications on school head. Malaysia: Euro Journals, 2(11) 42-51 